DOI: 10.17951/lrp.2018.37.4.187-201

\author{
MARIA Kocór \\ Krakowska Akademia im. Andrzeja Frycza Modrzewskiego \\ https://orcid.org/0000-0002-8253-8052
}

\title{
TERAŹNIEJSZOŚĆ I ZMIANA EDUKACJI SZKOLNEJ W ŚWIETLE WŁASNYCH ROZWAŻAŃ I BADAŃ
}

\begin{abstract}
Streszczenie: W artykule autorka akcentuje głęboki sens edukacji, jej stan i specyfikę zmian w ustroju demokratycznym w Polsce. Posiłkując się wynikami badań empirycznych prowadzonych od lat wśród nauczycieli jako głównych realizatorów zmian, poszukuje pedagogicznego wymiaru tych przeobrażeń. Zastanawia się nad przyszłością szkolnej edukacji i jej determinantami. Eksponuje wciąż ważne życiowe wartości, ku jakim powinna zmierzać, tj. prawdę, dobro i piękno przełożone na ludzką życzliwość, uczciwość i sumienność. Analizując je, można dojść do wniosku, że najwyższy czas „zawrócić z krętej, niepewnej i niebezpiecznej ścieżki na prostą, oświetloną drogę” prowadzącą do edukacji, która będzie narodowym priorytetem i katalizatorem rozwoju.
\end{abstract}

Słowa kluczowe: szkoła, edukacja, teraźniejszość, zmiana, rozwój

\section{WPROWADZENIE}

Współczesny świat podlega coraz głębszym i bardziej intensywnym przeobrażeniom w różnych dziedzinach życia: polityce, prawie, gospodarce, systemie społecznym i kulturowym, edukacji. Dokonujące się zmiany obejmują sposoby myślenia, systemy wartości, postawy, wzorce kulturowe przenoszone z kultury zachodniej i cyberprzestrzeni. W zmienną rzeczywistość polityczną, gospodarczą i społeczną „wplątane” są też stałość i tradycja, czyli to, co uchodzi za znamienne dla danego państwa i społeczeństwa, jego historii, kultury regionu i społeczności lokalnej.

Za najbardziej korzystne dla współczesnego systemu społecznego można uznać te jego elementy, których skuteczność pozostaje wciąż wysoka, mimo zmieniających się potrzeb i oczekiwań. Tak też jest z systemem edukacji, który zgodnie z ideą edukacji ustawicznej obejmuje wszystkie typy szkół i etapy kształcenia. Stałość i zmiana wpisują się bowiem w naukę, edukację, rozwój i życie jednostek oraz 
wspólnot (zob. Maszke 1995). Teraźniejszość to konsekwencja zmian, jakie dokonały się w przeszłości, a przyszłość będzie efektem tego, co wyniesiemy z teraźniejszości oraz przeobrażeń, które dopiero nastąpią $\mathrm{w}$ wyniku perspektywicznego myślenia, konsensusu społecznego czy też mało racjonalnych i przemyślanych decyzji reformatorskich narzuconych szkole oraz społeczeństwu. Przyszłość edukacji powinna być projektowana na podstawie rzetelnej diagnozy jej obecnego stanu i świadomości jej atutów, ale też krytycznej oceny popełnionych błędów i niedociągnięć. Wykorzystywanie wyników diagnozy istniejącego stanu w projektowaniu reform szkolnych jest konieczne do uświadamiania sobie, co powinno się wzmacniać, a co należy wycofać, zmienić, skorygować, udoskonalić. Czy w polskiej polityce oświatowej projektowanie zmian opiera się na gruntownej diagnozie mocnych i słabych stron edukacji szkolnej $\mathrm{w}$ celu wzmacniania stanów dobrych, a eliminowania złych i naprawiania błędów? Edukacja obejmuje proces kształcenia, wychowania i opieki, samokształcenia i samowychowania przez motywację do pracy nad sobą. W systemie demokratycznym wymaga trójpodmiotowej współpracy uczniów, nauczycieli, rodziców.

Ukazane problemy wydają się bardzo złożone, bo obejmują wiele zagadnień z zakresu polityki oświatowej, pedagogiki szkolnej, pedeutologii i nauk pomocniczych. Dla pedagogiki teoretycznie i praktycznie zorientowanej niezmiernie istotne jest bowiem podejmowanie ciągłej refleksji nad aktualnym i przyszłym stanem edukacji oraz ich uwarunkowaniami, ze szczególnym akcentem na teraźniejszą i przyszłą szkołę. Artykuł ma na celu ukazanie specyfiki i wymiaru współczesnej edukacji, który jest konsekwencją zarówno dokonujących się przeobrażeń, jak i tego, co pozostawiła przeszłość. Na tle krytycznej diagnozy stanu edukacji szkolnej oraz jego źródeł warto podjąć dyskusję nad przyszłą szkołą w poszukiwaniu zmian ukierunkowanych na urzeczywistnianie wartości takich jak dobro, prawda i piękno przełożone na ludzką życzliwość, uczciwość i sumienność.

Podejmując zagadnienie teraźniejszości i zmiany prowadzącej ku lepszej edukacji, ale też stawiającej ją pod znakiem zapytania, kiedy jest źle zaplanowana i mało udana, autorka odwołuje się do wyników własnych badań empirycznych prowadzonych w szkołach różnego typu i szczebla, jak też obserwacji i doświadczeń ze szkołą związanych. Analizując nastawienie głównych podmiotów szkoły do wybranych aspektów rzeczywistości szkolnej, szuka odpowiedzi na pytania:

1. Ku czemu zmierza edukacja?

2. Jaki jest jej stan oczekiwany i osiągany?

3. Jak zbliżać do siebie dwa „światy” - postulowany i rzeczywisty - by w przyszłości „teraźniejszość edukacji” była wynikiem zmian pedagogicznie wartościowych?

Niełatwe to pytania, obejmujące wiele problemów i zagadnień związanych z warunkami, planowaniem i organizowaniem, kontrolowaniem i ocenianiem, 
doskonaleniem i zmienianiem edukacji w szkole. Artykuł można potraktować jako zachętę czy prowokację do refleksyjnego myślenia i krytycznej dyskusji o teraźniejszej oraz przyszłej szkole. W pierwszej kolejności warto jednak uświadomić sobie sens edukacji w społeczeństwie demokratycznym i jej najważniejsze cele.

\section{EDUKACJA I SZKOŁA - ICH SENS I WARTOŚĆ DLA JEDNOSTKI I SPOŁECZEŃSTWA}

W dobie globalizacji, a z drugiej strony rozwoju lokalności w każdym państwie i społeczeństwie niezmiernie ważne są edukacja i szkoła oraz ich reformowanie wobec kryzysu wychowawczego współczesnej rodziny i wzrastającej roli Internetu. W warunkach demokracji i samorządności edukacja ma sens jednostkowy i wspólnotowy. Służy bowiem dobru pojedynczych obywateli, a dzięki temu i dobru społecznemu. Ze słowem dobro wiążą się wartości takie jak: prawda i piękno, a także ludzka życzliwość, uczciwość, sumienność, szacunek, zaufanie, zaangażowanie i odpowiedzialność za ich skutki. Sensem, a zarazem wartością edukacji jest czynienie dobra i troska o rozwój dzieci, młodzieży, dorosłych. Inwestując w edukację i wykształcenie ludzi zdolnych do autonomicznego myślenia i działania, wyznających humanistyczne wartości, przyczyniamy się do rozwoju społeczeństwa obywatelskiego. Jest ono świadome, kreatywne i odpowiedzialne za „teraźniejszość” i „przyszłość” różnych dziedzin życia, w tym za „dziś” i „jutro” edukacji szkolnej, od której wiele się zaczyna i wiele zależy. Jaki więc sens ma edukacja dla jednostki i jaką wartość niesie dla społeczeństwa? Po pierwsze, ukierunkowuje człowieka i wzmacnia jego potencjał. Pomaga w rozwiązywaniu trudnych problemów, jak też w roztaczaniu opieki nad uczniem, gdy sobie nie radzi i uczeniu go zaradności życiowej. Po drugie, poprzez kreowanie światłych i dojrzałych obywateli przyspiesza zmiany rozwojowe. Edukacja to bowiem proces całożyciowy, ukierunkowany na kształtowanie postaw i umiejętności oraz nabywanie wartościowej w życiu wiedzy. Dlatego warto uświadomić sobie jej sens i składowe, uwarunkowania i specyfikę zmian.

Najważniejszą instytucją edukacyjną jest szeroko rozumiana szkoła: podstawowa, średnia, ale też szkoła wyższa, szkoła ogólna i zawodowa, wiejska i miejska, mała i duża, niepubliczna i publiczna. Rozważania ograniczono do tej ostatniej, czyli do szkoły ogólnodostępnej w Polsce.

Z założenia szkoła jest miejscem edukacji i rozwoju uczniów, ale też miejscem pracy i rozwoju nauczycieli. Ma więc wymiar osobowy i instytucjonalny czy szerzej - społeczny. Cele i założenia tej instytucji są zapisane w różnych aktach prawnych, statutach, regulaminach, które określają organizację pracy na podstawie 
zawartych w nich zasad. W szkole panują więc pewne warunki, normy i wzorce zachowań będące pozostałością przeszłości i wynikiem dokonujących się zmian. Myślimy o szkole, która nas uczyła oraz o funkcjonującej obecnie. Świadomość mocnych i słabych stron teraźniejszej i przeszłej szkoły, jak również oczekiwań i realiów pozwala planować przemyślane, merytorycznie zasadne, ale też możliwe do przeprowadzenia reformy ukierunkowane na jej dobro i rozwój. Co zatem składa się na proces edukacji szkolnej i jakie ma uwarunkowania? Poszukiwanie odpowiedzi na to pytanie wydaje się ważne dla powodzenia reform szkolnych oraz budowania dobrej, przyjaznej szkoły.

\section{PROCES EDUKACJI SZKOLNEJ - SKŁADOWE I UWARUNKOWANIA}

Edukacja w szkole to proces trudny i złożony, gdyż zależy nie tylko od jej podmiotów, ale od ogólnego klimatu i charakteru polityki zmian oświatowych, reform społecznych, gospodarczych itp. Od lat różni badacze akcentowali związek edukacji i szkoły z systemem społecznym i kulturowym, twierdząc, iż reforma szkoły wymaga przekonania i zaangażowania społeczeństwa, zmiany jego myślenia. Zaznaczali, że aby zmienić system społeczny i kulturę, trzeba zacząć od edukacji oraz jej reform (Szczepański 1989, Kwieciński 1995, Sawisz 1989). Edukacja w szkole ma więc wymiar indywidualny, w którym liczy się dotarcie do wnętrza każdego ucznia i ukierunkowanie go na akcentowane wcześniej wartości, ale też instytucjonalny, związany z warunkami materialnymi, technicznymi i organizacją. Ma także aspekt społeczny, odnoszący się do klimatu i kultury szkoły, panujących w niej stosunków, postaw i zachowań. Zatem analizowanie i ocenianie procesu edukacji musi dokonywać się z jednej strony poprzez tzw. pomiar zmiennych i dobór wskaźników adekwatnych do realiów szkolnych, z drugiej strony zaś poprzez badania jakościowe nastawione na zrozumienie i kontekst społeczno-kulturowy szkoły (Woods 1986, Janowski 1989, Kawecki 1993 i inni). Te dwa podejścia wynikają z instytucjonalnego, społecznego wymiaru szkoły, ale też z potrzeby postrzegania edukacji i jej efektów w aspekcie indywidualnym, jednostkowym.

Składnikami edukacji szkolnej są elementy typowe dla edukacji w ogóle. Każda bowiem edukacja, niezależnie od typu szkoły, ma swoje: cele i wartości, treści, metody, formy i środki, warunki materialne (a więc infrastrukturę, wyposażenie) i warunki społeczne oraz kulturowe (atmosferę i klimat, role podmiotowe, kontrolę osiągnięć i doskonalenie). Te pierwsze elementy ściśle wiążą się z aksjologią edukacyjną, następne $\mathrm{z}$ określoną strategią, planowaniem treści i zakresu edukacji, ostatnie zaś z organizowaniem, czyli ze stosowaniem określonych działań i metod oraz z wykorzystaniem odpowiednich środków. Wszystkie te komponenty 
są usytuowane w przestrzeni edukacyjnej, na którą składają się warunki fizyczne, psychiczne, społeczne, w tym stan budynków, dostęp do sal i klasopracowni, jak również klimat szkoły, atmosfera panująca w klasie, stosunki społeczne, normy, postawy wobec szkoły, edukacji i jej podmiotów, systemy wartości, przekonania, ale też trudności, konflikty itp. Czynniki te wiążą się z kontrolą i ewaluacją, z doskonaleniem, reformowaniem. Także ocenianie pracy uczniów, nauczycieli i szkoły oraz wdrażanie zmian i innowacji, urzeczywistnianie założeń reformatorskich są determinantami i wyznacznikami edukacji.

Od czego więc zależy jakość edukacji szkolnej? Niewątpliwie od czynników wewnętrznych i zewnętrznych, podmiotowych i pozapodmiotowych, instytucjonalnych, środowiskowych i osobowościowych. W szczególności zaś ma związek z polityką oświatową, warunkami, w jakich szkoła funkcjonuje, jak też ze stylami myślenia, postawami, zachowaniami jej uczestników i współpracą ze środowiskiem. Te ostatnie czynniki są pochodną szerszych procesów społecznych i stanu społeczeństwa obywatelskiego. Dotyczą uczelni wyższych kształcących przyszłą kadrę.

Najbardziej istotne w realizacji założeń związanych z kształtowaniem postaw i rozwijaniem umiejętności oraz nabywaniem wiedzy wydają się cechy nauczyciela i klasy szkolnej jako grupy formalnej i nieformalnej. Kompetencje zawodowe nauczyciela i jego podmiotowy, motywacyjny stosunek do uczniów pełnią bardzo istotną rolę w budowaniu atmosfery w klasie i w aktywizowaniu uczniów. Skoro tak wiele zależy od nauczyciela, od jego kompetencji, motywacji, ale też warunków, jakie ma i może kreować, warto skupić się na jego przekonaniach i doświadczeniach, poszukując odpowiedzi na pytania:

1. Czy dokonane i dokonujące się reformy służą osiąganiu celów edukacji i dobru jej uczestników?

2. Na ile reformy te są pożyteczne i wartościowe?

3. Jak przedstawia się „teraźniejszość edukacji” w kontekście polityki reform i doświadczeń szkolnych podmiotów?

Pytania te stały się inspiracją do rozważań w kolejnych punktach opracowania.

\section{PODSTAWY METODOLOGICZNE WŁASNYCH ROZWAŻAŃ I BADAŃ}

Początków badań i rozważań podejmowanych przez autorkę w niniejszym temacie należy szukać już w pierwszej dekadzie zmian demokratyzujących życie szkoły (1989-1999). Badania sondażowe wśród nauczycieli różnych typów szkół miejskich i wiejskich były prowadzone w dwóch etapach. Pierwsze miały charakter ogólnopolski i objęły grupę tysiąca osób z różnych regionów kraju tuż przed słynnym wrześniem 1999 roku, kiedy to miała ruszyć reforma oświaty (Kocór 
2006). Nauczyciele wyrażali swój stosunek do zachodzących przeobrażeń oraz oceniali rzeczywistość szkoły kształtującą się w ich efekcie. W badaniach posłużono się w metodą sondażu i techniką ankiety. Opracowany kwestionariusz składał się z kilku części. Jedna z nich dotyczyła oceny przemian w pierwszej dekadzie transformacji ustrojowej w Polsce. Był to cenny okres tworzenia prawnych i organizacyjnych podstaw demokracji w edukacji. Druga część ankiety odnosiła się do postaw nauczycieli wobec reformy, której realizację rozpoczęto 1 września 1999 roku wprowadzeniem nowego ustroju szkolnego.

Kolejne badania dotyczące opinii i doświadczeń nauczycieli związanych z reformą z 1999 roku zostały przeprowadzone w latach 2005-2008 wśród 723 nauczycieli z różnych typów szkół na terenie województw podkarpackiego i małopolskiego. Badani byli w różnym wieku. Posiadali różne stopnie awansu zawodowego, jednak wszyscy należeli do doświadczonej kadry o wysokich kwalifikacjach. Były to głównie kobiety, które ukończyły uniwersytet, wyższą szkołę pedagogiczną lub akademię pedagogiczną.

$\mathrm{W}$ prowadzonych trójetapowo badaniach autorkę interesowało nastawienie nauczycieli do reformy przed i po jej urzeczywistnieniu. Trudno jednak o pełne informacje i wnioski, ponieważ pierwsza próba była ogólnopolska (z miast takich jak: Rzeszów, Tarnów, Kraków, Nowy Sącz, Przeworsk, Przemyśl, Olsztyn, Gdańsk, Warszawa i przyległych do nich miejscowości), natomiast w latach 2005-2008 grupa badawcza została wyłoniona spośród kadry wybranych szkół na terenie Podkarpacia i Małopolski.

Badania prowadzone w przededniu reformy uwzględniały nie tylko stosunek nauczycieli, gotowość do jej urzeczywistniania i obawy związane z wprowadzeniem długo oczekiwanych zmian. Ankietowaną kadrę pytano również o: merytoryczną zasadność reformy, ocenę jej przygotowania i stopień poparcia, a także obawy i chęć uczestnictwa w zmianach. W kolejnych latach kwestionariusz ankiety został uzupełniony o pytania odnoszące się do kilkuletnich doświadczeń reformatorskich nauczycieli i dostrzeganych przez nich skutków zmian. Założenia metodologiczne i wyniki tych badań autorka częściowo opublikowała (Kocór 2006, 2010, 2011, 2012c, 2014a, 2015c, 2016b). Niektóre zagadnienia wymagają jednak poszerzenia i będą upowszechnione razem $\mathrm{z}$ wynikami badań prowadzonych nad kolejna reformą, zgodną z Ustawą z dnia 14 grudnia 2016 r. Prawo oświatowe (Dz.U. 2017).

Związek z tematem dotyczącym postrzegania teraźniejszości szkolnej w różnych aspektach i dokonanych przeobrażeń mają też badania nad oczekiwaniami uczniów wobec szkoły i jej zmian (Kocór 2012d, 2014), nad problemami, stresem i wsparciem w szkole (Kocór 2010, 2015a, 2015b, 2016a, 2017, 2018), nad funkcjonowaniem, kompetencjami i autorytetem nauczyciela-wychowawcy (Kocór 2012a, 2012b, 2016c) itp. Uzyskane wyniki, własne doświadczenia, obserwacje i przemyślenia pozwoliły na podjęcie próby zestawienia składowych edukacji szkolnej w kontekście teraźniejszości i przyszłości. 


\section{TERAŹNIEJSZOŚĆ I ZMIANA EDUKACJI SZKOLNEJ W ŚWIETLE PROWADZONYCH BADAŃ}

Jak zatem postrzegają teraźniejszą szkołę i edukację jej podmioty? Jakie są ich przekonania i doświadczenia dotyczące dokonujących się zmian? Pytania te wydają się niezmiernie ważne, ale też bardzo złożone, bo wymagają analizy poszczególnych składników edukacji, jej: założeń, warunków i sposobów realizacji, postaw i zachowań podmiotów szkoły, kryteriów i metod oceniania efektów oraz ich doskonalenia. W tym krótkim tekście nie sposób opisać wszystkich elementów edukacji, ale można zwrócić uwagę na potrzebę konfrontacji teraźniejszości oraz zmiany w przekonaniach i doświadczeniach jej najważniejszych podmiotów.

Tabela 1. Teraźniejszość i zmiana edukacji szkolnej w świetle prowadzonych badań

\begin{tabular}{|c|c|c|}
\hline $\begin{array}{c}\text { Edukacja } \\
\text { szkolna } \\
\text { i jej składowe }\end{array}$ & $\begin{array}{l}\text { Teraźniejszość edukacji i jej cechy } \\
\text { (jaka?) }\end{array}$ & $\begin{array}{c}\text { Zmiana edukacji - postulowana } \\
(\text { (jaka?) }\end{array}$ \\
\hline $\begin{array}{l}\text { Planowanie } \\
\text { edukacji - } \\
\text { założenia, } \\
\text { cele i treści }\end{array}$ & $\begin{array}{l}\text { Edukacja w dużej mierze wciąż opiera się } \\
\text { na założeniach pedagogiki instrumental- } \\
\text { no-adaptacyjnej mówiącej o tym, że szkoła } \\
\text { ma uczyć adaptacji ludzi do zastanych } \\
\text { warunków bytu, wykonywania odgór- } \\
\text { nych poleceń i decyzji, bez dyskutowania } \\
\text { z nimi czy odczuwania ich merytorycznej } \\
\text { zasadności i potrzeby (zob. Kocór 2006, } \\
\text { 2014a, 2015a); } \\
\text { Działania edukacyjne często jeszcze mają } \\
\text { u swych podstaw diagnozy potrzeb i moż- } \\
\text { liwości uczniów (i nauczycieli), a przez to } \\
\text { prowadzą do „niedopasowania” szkoły do } \\
\text { ucznia (i nauczyciela) w wielu aspektach; } \\
\text { Nauczyciele są niechętni do prowadzenia } \\
\text { badań dla rozwoju teorii i praktyki edu- } \\
\text { kacyjnej (Kocór 2016c, 2017, 2018b); } \\
\text { W hierarchii celów wciąż prym wiedzie } \\
\text { „wyposażanie” uczniów w mało przydatną } \\
\text { w życiu wiedzę, którą powinni nabywać } \\
\text { sami, dyskutować, weryfikować w praktyce, } \\
\text { jak też budować nową na bazie doświadcze- } \\
\text { nia (zob. Kocór 2014b, 2015a, 2016a, 2016b); }\end{array}$ & $\begin{array}{l}\text { Powinna nastąpić zmiana paradygmatu } \\
\text { z edukacji instrumentalno-adaptacyjnej } \\
\text { na krytyczno-twórczą, rozwijającą } \\
\text { autonomię myślenia i działania. Należy } \\
\text { zwrócić się ku refleksyjnemu modelowi } \\
\text { edukacji, w którym ważne są poczucie } \\
\text { odpowiedzialności za jej skutki oraz kom- } \\
\text { petencje, a nie tylko kwalifikacje; } \\
\text { Konieczne jest nowe spojrzenie na potrze- } \\
\text { bę i sens: diagnozy w szkole i dla szkoły, } \\
\text { rozwijania teorii poprzez prowadzenie } \\
\text { badań z udziałem nauczycieli praktyków } \\
\text { i naukowców, doskonalenia praktyki } \\
\text { szkolnej; } \\
\text { Powinno dojść do zmiany hierarchii } \\
\text { celów edukacji z „wyposażania” uczniów } \\
\text { w wiedzę na refleksyjne i twórcze uczenie } \\
\text { się, rozwiązywanie problemów, ekspery- } \\
\text { mentowanie oraz krytyczność myślenia } \\
\text { o szkole i edukacji w celu poszukiwania } \\
\text { innowacji, z wykorzystaniem metody sa- } \\
\text { morządu uczniowskiego do kształtowania } \\
\text { postaw podmiotowych; }\end{array}$ \\
\hline
\end{tabular}




\begin{tabular}{|c|c|c|}
\hline $\begin{array}{c}\text { Edukacja } \\
\text { szkolna } \\
\text { i jej składowe }\end{array}$ & $\begin{array}{l}\text { Teraźniejszość edukacji i jej cechy } \\
\text { (jaka?) }\end{array}$ & $\begin{array}{c}\text { Zmiana edukacji - postulowana } \\
(\text { (jaka?) }\end{array}$ \\
\hline $\begin{array}{l}\text { Planowanie } \\
\text { edukacji - } \\
\text { założenia, } \\
\text { cele i treści }\end{array}$ & $\begin{array}{l}\text { Problemem stał się przesyt i rozdrobnie- } \\
\text { nie treści programowych, które uczniowie } \\
\text { niechętnie zgłębiają. Wiele przedmiotów } \\
\text { i zajęć dydaktycznych jest mało atrak- } \\
\text { cyjnych, mało motywujących do nauki } \\
\text { i rozwoju, nudnych dla uczniów, którzy } \\
\text { przeszkadzają na lekcjach (Kocór 2016a, } \\
\text { 2016c, 2017); } \\
\text { W teraźniejszej edukacji niepokojące są } \\
\text { nadmiar troski o funkcję dydaktyczną } \\
\text { szkoły, a także lekceważenie czy wręcz } \\
\text { czasowa i kompetencyjna bezradność } \\
\text { nauczycieli (Kocór 2015a) wobec spraw } \\
\text { wychowania uczniów, ich potrzeb, } \\
\text { zrozumienia, uznania, zaufania. Przez to } \\
\text { zatraca się dusza szkoły, do której rosnącą } \\
\text { niechęć czują tak uczniowie, jak i na- } \\
\text { uczyciele, bezsilni wobec coraz większej } \\
\text { biurokracji. Wielu uczniów i nauczycieli } \\
\text { rywalizuje ze sobą zamiast współpraco- } \\
\text { wać (Kocór 2016). }\end{array}$ & $\begin{array}{l}\text { Konieczne jest postawienie w kształce- } \\
\text { niu i przyjmowaniu do pracy w szkole } \\
\text { na twórczych nauczycieli z pasją, którzy } \\
\text { kochają pracę z uczniem, są pasjonatami } \\
\text { swoich przedmiotów, przygotowują się } \\
\text { i prowadzą atrakcyjne zajęcia; } \\
\text { Potrzeba większej troski o funkcję } \\
\text { wychowawczą, opiekuńczą, środowi- } \\
\text { skową, kulturową szkoły, z akcentem } \\
\text { na kształtowanie wartości i postaw, na } \\
\text { których opiera się wewnętrzna motywacja } \\
\text { uczniów do nauki. }\end{array}$ \\
\hline $\begin{array}{l}\text { Realizacja - } \\
\text { metody, } \\
\text { formy i środki }\end{array}$ & $\begin{array}{l}\text { Ciągle mało skuteczne oraz mało dosto- } \\
\text { sowane do indywidualnych możliwości } \\
\text { i potrzeb uczniów są metody osiągania } \\
\text { celów edukacji, o których wyżej mowa. } \\
\text { Mało wykorzystuje się zasoby szkoły } \\
\text { i naturalnego środowiska przy wcielaniu } \\
\text { w życie twórczych pomysłów angażujące- } \\
\text { go uczniów nauczyciela-pasjonata; } \\
\text { Wielu uczących nie potrafi efektywnie } \\
\text { wykorzystywać technologii informacyjnej } \\
\text { w pracy, jest w tyle za umiejętnościami } \\
\text { uczniów. Często na lekcjach stosuje się } \\
\text { metody podające: tradycyjne przepisywa- } \\
\text { nie z tablicy czy z komputera, dyktowanie } \\
\text { treści do zeszytów jako tzw. notatek } \\
\text { do wyuczenia. Mało się dyskutuje i nie } \\
\text { stwarza się pola do polemiki nad inte- } \\
\text { resującymi zagadnieniami czy treściami } \\
\text { programowymi. „Przerabia się” materiał, } \\
\text { „realizuje” podręcznik (Kocór 2012a, } \\
\text { 2014b). }\end{array}$ & $\begin{array}{l}\text { Nieodzowne wydaje się wprowadzenie } \\
\text { metod bardziej angażujących ucznia do } \\
\text { twórczego udziału w zajęciach. Sprawdzi- } \\
\text { łyby się np. metody projektowe z wyko- } \\
\text { rzystaniem uczniowskich inicjatyw, orga- } \\
\text { nizowanie warsztatów, zajęć w plenerze, } \\
\text { na łonie natury, w laboratoriach. War- } \\
\text { tościowe może okazać się wykorzystanie } \\
\text { informatycznego potencjału uczniów do } \\
\text { pozyskiwania, konfrontacji, weryfikacji } \\
\text { wiedzy z różnych źródeł. Istotne jest też } \\
\text { uczenie dobrej organizacji pracy i współ- } \\
\text { pracy w grupie; } \\
\text { Metody pracy z uczniem trudnym, zdol- } \\
\text { nym, o specjalnych potrzebach powinny } \\
\text { być oparte na wysokich kompetencjach } \\
\text { kadry pedagogicznej w szkołach. }\end{array}$ \\
\hline
\end{tabular}




\begin{tabular}{|c|c|c|}
\hline $\begin{array}{c}\text { Edukacja } \\
\text { szkolna } \\
\text { i jej składowe }\end{array}$ & $\begin{array}{c}\text { Teraźniejszość edukacji i jej cechy } \\
\text { (jaka?) }\end{array}$ & $\begin{array}{c}\text { Zmiana edukacji - postulowana } \\
(\text { (jaka?) }\end{array}$ \\
\hline $\begin{array}{l}\text { Przestrzeń } \\
\text { edukacyjna - } \\
\text { warunki } \\
\text { materialne, } \\
\text { techniczne } \\
\text { i kultura }\end{array}$ & $\begin{array}{l}\text { Infrastruktura i wyposażenie w sprzęt } \\
\text { oraz pomoce dydaktyczne są różne w róż- } \\
\text { nych szkołach. Wiele małych środowisk } \\
\text { boryka się z problemami natury finanso- } \\
\text { wej z racji niskiej dotacji od samorządów } \\
\text { lokalnych, które stawiają na szybki zysk } \\
\text { „tu i teraz”. Nie chcą myśleć perspekty- } \\
\text { wicznie, inwestując w oświatę i rozwój } \\
\text { społeczeństwa. Dlatego wiele szkół w ma- } \\
\text { łych miejscowościach jest zagrożonych } \\
\text { likwidacją, a pracujący w nich nauczyciele } \\
\text { obawiają się wciąż o pracę, rosną ich } \\
\text { frustracja, rozczarowanie i apatia (por. } \\
\text { Kocór 2014a, 2015b). Te małe środowiska } \\
\text { lokalne mają nierówne szanse w stosunku } \\
\text { do większych środowisk o dużych możli- } \\
\text { wościach inwestycyjnych, gospodarczych } \\
\text { i finansowych, o wzmożonej ruchliwości } \\
\text { społecznej i wysokiej kulturze edukacji. } \\
\text { Z zagadnieniami tymi wiążą się nie tylko } \\
\text { aspekty materialno-techniczny i finanso- } \\
\text { wy, ale też kultura pracy szkoły, kwestie } \\
\text { nierównego startu i możliwości rozwo- } \\
\text { jowych. W badaniach własnych często } \\
\text { akcentowane były kwestie odmiennych } \\
\text { systemów wartości, głównie pedagogów } \\
\text { i decydentów oświatowych, sprzeczności } \\
\text { ról, interesów, konflikty wewnętrzne czy } \\
\text { pokoleniowe, często dziś obecne w oświa- } \\
\text { cie i w szkole (Kocór } 2006,2010,2011, \\
2014 a, 2016 b) ; \\
\text { Wciąż czyni się mało starań o integrację } \\
\text { działań dla wspólnej przestrzeni edukacyj- } \\
\text { nej na miarę społeczeństwa obywatelskiego. }\end{array}$ & $\begin{array}{l}\text { Przestrzeń szkoły wymaga diametralnej } \\
\text { odnowy, głównie jeśli chodzi o techniczną } \\
\text { stronę sugerującą władzę nauczyciela sie- } \\
\text { dzącego frontem do uczniów, za biurkiem, } \\
\text { z dziennikiem, do którego wpisuje oceny, } \\
\text { uwagi i inne służbowe notatki. Trudno } \\
\text { o refleksyjną edukację angażująca twórczy } \\
\text { potencjał uczniów, jeśli sale będą skrom- } \\
\text { nie wyposażone, urządzone tradycyjnie, } \\
\text { surowo, w sposób przestarzały, ozdobione } \\
\text { gazetkami, na których pojawiają się nud- } \\
\text { ne informacje. Jeśli szkoła nie zainwestuje } \\
\text { w dobry sprzęt i wystrój, to trudno mówić } \\
\text { o projektach, eksperymentach, o klima- } \\
\text { cie zaufania, szczerości, zaangażowania } \\
\text { w uczenie się, z którego tak uczeń, jak } \\
\text { i nauczyciel będą czerpać motywację } \\
\text { i satysfakcję. Jeśli ławki szkolne i biurka } \\
\text { uczących nadal będą sugerować, kto } \\
\text { posiada w szkole władzę i dyktuje warun- } \\
\text { ki, nie zaistnieją partnerskie stosunki, } \\
\text { a uczniowie nie będą mieć udziału w tzw. } \\
\text { dobrej zmianie. Niezmiernie ważne wy- } \\
\text { daje się więc eliminowanie napotykanych } \\
\text { ograniczeń i stereotypów, przekraczanie } \\
\text { granic i barier. }\end{array}$ \\
\hline $\begin{array}{l}\text { Podmioty } \\
\text { edukacji, } \\
\text { ich postawy } \\
\text { i relacje }\end{array}$ & $\begin{array}{l}\text { Szczególnego traktowania wymaga klimat } \\
\text { szkoły i edukacji (Kocór 2017, 2018a), } \\
\text { który tworzą jej uczestnicy: uczniowie, } \\
\text { rodzice, nauczyciele podejmujący dialog } \\
\text { i współpracę w planowaniu, realizacji, } \\
\text { ewaluacji i doskonaleniu działań edu- } \\
\text { kacyjnych w szkole jako tzw. partnerzy. } \\
\text { Z partnerstwem wiążą się poszanowanie, } \\
\text { równość praw, zaufanie, uznanie, zaanga- } \\
\text { żowanie i odpowiedzialność; }\end{array}$ & $\begin{array}{l}\text { Mówiąc o wewnętrznej zmianie szkoły - } \\
\text { jej duszy i klimatu oraz atmosfery panują- } \\
\text { cej na lekcjach - nie sposób nie wspo- } \\
\text { mnieć, czym jest partnerstwo edukacyjne } \\
\text { bądź też partnerstwo dla rozwoju. Z jego } \\
\text { odpowiednim traktowaniem i wykorzy- } \\
\text { staniem wiążą się wzajemna akceptacja } \\
\text { i poszanowanie, równość szans, świado- } \\
\text { mość praw i obowiązków; }\end{array}$ \\
\hline
\end{tabular}




\begin{tabular}{|c|c|c|}
\hline $\begin{array}{c}\text { Edukacja } \\
\text { szkolna } \\
\text { i jej składowe }\end{array}$ & $\begin{array}{l}\text { Teraźniejszość edukacji i jej cechy } \\
\text { (jaka?) }\end{array}$ & $\begin{array}{c}\text { Zmiana edukacji - postulowana } \\
\text { (jaka?) }\end{array}$ \\
\hline $\begin{array}{l}\text { Podmioty } \\
\text { edukacji, } \\
\text { ich postawy } \\
\text { i relacje }\end{array}$ & $\begin{array}{l}\text { W badaniach jednak często ujawniają się } \\
\text { odmienne oczekiwania, priorytety szkol- } \\
\text { nych podmiotów (Kocór 2012a, 2014b), } \\
\text { wytykanie błędów zamiast poszukiwania } \\
\text { rozwiązań z wykorzystaniem ich poten- } \\
\text { cjału. Można na ich podstawie powie- } \\
\text { dzieć, że zmiany demokratyczne wciąż } \\
\text { w małym stopniu postępują w świado- } \\
\text { mości i postawach podmiotów szkolnych. } \\
\text { Wśród nauczycieli, którzy często kojarzą } \\
\text { funkcje założone szkoły z rzeczywisty- } \\
\text { mi, od lat dominują instrumentalizm } \\
\text { i adaptacyjność. Afirmują oni swoją pracę } \\
\text { i kompetencje, podczas gdy uczniowie } \\
\text { oceniają ich bardziej krytycznie. }\end{array}$ & $\begin{array}{l}\text { Za najistotniejsze należy uznać prze- } \\
\text { konanie o merytorycznej potrzebie } \\
\text { partnerstwa, chęć współpracy, zaangażo- } \\
\text { wanie i poczucie odpowiedzialności. Aby } \\
\text { partnerstwo służyło budującej krytyce } \\
\text { i lepszej edukacji, potrzeba jednak zmiany } \\
\text { mentalnej. Do budowania partnerstwa } \\
\text { i dobrego klimatu w szkole niezbędne jest } \\
\text { wykorzystanie metody samorządu ucz- } \\
\text { niów, rodziców, nauczycieli z dyrektorem } \\
\text { na czele. Dzięki samorządności i partner- } \\
\text { stwu edukacja to „wspólne dzieło”. }\end{array}$ \\
\hline $\begin{array}{l}\text { Ocena } \\
\text { i ewaluacja } \\
\text { (kryteria, } \\
\text { sposoby) }\end{array}$ & $\begin{array}{l}\text { Obowiązujące od lat kryteria oceny pracy } \\
\text { tak ucznia, jak i nauczyciela czy szko- } \\
\text { ły są sztuczne, mało zasadne i niezbyt } \\
\text { przekonujące. Liczą się tylko punkty } \\
\text { w teście, różne sprawozdania, zaświadcze- } \\
\text { nia, dyplomy i świadectwa, które często } \\
\text { nie świadczą o kompetencjach i wysokiej } \\
\text { jakości działań. Ważna jest bowiem } \\
\text { ocena modelująca (a nie oceny dla ocen) } \\
\text { akcentująca dobre strony edukacji, ale też } \\
\text { błędy i potknięcia, by ich w przyszłości } \\
\text { unikać. Służą temu planowane zmiany } \\
\text { w szkole, których inicjatorami powinni } \\
\text { być nie tylko nauczyciele, ale też rodzice } \\
\text { i uczniowie. }\end{array}$ & $\begin{array}{l}\text { Kryteria zarówno oceniania pracy ucznia, } \\
\text { nauczyciela, jak i ewaluacji pracy szkoły } \\
\text { trzeba zmienić na jakościowe, akcentujące } \\
\text { w pierwszej kolejności etyczne i krytyczne } \\
\text { postawy, twórcze zaangażowanie w stawa- } \\
\text { nie się lepszym, bardziej zmotywowanym, } \\
\text { wartościowym uczestnikiem szkolnej } \\
\text { edukacji, odpowiedzialnym za jej efekty } \\
\text { i jakość. Wymagają one większego prze- } \\
\text { konania oraz przygotowywania nauczy- } \\
\text { cieli do zmian i innowacji. }\end{array}$ \\
\hline $\begin{array}{l}\text { Specyficzne } \\
\text { cechy }\end{array}$ & $\begin{array}{l}\text { Teraźniejsza edukacja szkolna ujawnia się } \\
\text { w instrumentalnej i adaptacyjnej osobo- } \\
\text { wości nauczyciela, w jego dużym poczuciu } \\
\text { sprawstwa, częstej krótkowzroczności, } \\
\text { „teatralności zachowań” (Janowski 1989), } \\
\text { małym wpływie (autorytecie) wychowaw- } \\
\text { czym na uczniów i niewielkiej motywacji } \\
\text { do stawania się świadomym sprawcą } \\
\text { rozwoju. }\end{array}$ & $\begin{array}{l}\text { Edukacja szkolna powinna być skiero- } \\
\text { wana na istotne w życiu wartości i cele - } \\
\text { zaufanie, uznanie, zaangażowanie, odpo- } \\
\text { wiedzialność. Ma do nich dążyć zarówno } \\
\text { szkoła, jak i jej podmioty, podejmujące } \\
\text { wysiłek stawania się lepszym uczniem, } \\
\text { rodzicem, obywatelem, nauczycielem. }\end{array}$ \\
\hline
\end{tabular}

Źródło: opracowanie własne na podstawie wyników badań sondażowych prowadzonych od lat wśród uczniów i nauczycieli. 
Wymienione cechy edukacji ucznia w szkole to tylko niektóre z akcentowanych przez badane podmioty niepokojących stanów wymagających zmian. W innym opracowaniu autorka oprócz błędów i niedociągnięć edukacji szkolnej wskazuje jej mocne strony, możliwe do wykorzystania przy planowaniu kolejnych reform (Kocór 2016d). Najbardziej niepokojące są jednak:

- zbyt płytkie wartości i cele edukacji związane ze sztucznym planowaniem, organizacją i „zaliczaniem” zajęć czy danych etapów kształcenia, które wciąż w małym stopniu dostarcza przydatnej w życiu wiedzy i kompetencji;

- style myślenia o edukacji, postawy szkolnych podmiotów i decydentów oświaty stanowiące barierę w edukacji uczniów skierowanej na stawanie się podmiotem swojego losu i rozwoju środowiska;

- mało udolne reformy i polityka oświatowa, mierzone innymi kryteriami niż pedagogiczne, często wprowadzające zmiany pozorne, niewiele wnoszące do rozwoju edukacji i jej uczestników;

- niski kapitał i postawy społeczeństwa mało nastawione na obywatelskie zaangażowanie, troskę o lepszą edukację i szkołę, a bardziej na urzędowość, krytykanctwo i roszczeniowość;

- krótkowzroczność działań szkolnych skierowanych na „zaliczanie” zajęć, testów, egzaminów i zdobywanie sztucznych stopni, które niewiele mają wspólnego z kompetencją (Kocór 2016d, 2016c). Na sens i wartość diagnozy oraz ewaluacji w szkołach w kontekście rozwijania twórczych kompetencji uczniów, doskonalenia praktyki edukacyjnej zwracają uwagę prace Josefa Malacha i innych $(2015,2016)$. Jak piszą autorzy, diagnoza i ewaluacja mają służyć edukacji nastawionej na indywidualne potrzeby i możliwości uczniów, pomagać ich orientacji zawodowej (Malach, Kristová 2016, s. 208).

Szansą na wprowadzenie zmian skutecznych dla rozwoju edukacji ucznia w szkole wydają się jej określone zasoby pedagogiczne i pozapedagogiczne, których istnienie warto sobie uświadamiać i w przyszłości z nich korzystać. Są nimi: otwartość na nowe idee, teorie pedagogiczne i wizje społeczne, dostęp do różnych źródeł wiedzy i wyników badań prowadzonych niemal na całym świecie. Edukację, przy założeniu, że będzie jej towarzyszyć troska o jej dobro i wspólne cele szkolnych podmiotów, mogą ochronić także duże możliwości w zakresie komunikacji i uczenia się na odległość, udziału w kulturze, aktywności sportowej i turystycznej, dbałości o zdrowie, organizowania czasu wolnego. Poza tym zmianom rozwojowym edukacji sprzyja postęp nauki, techniki i medycyny. $\mathrm{W}$ tym wszystkim najważniejszy jest jednak człowiek, jego dobre relacje ze światem i z sobą, do budowania których powinna przygotować ucznia właśnie edukacja, mająca u swych podstaw najważniejsze humanistyczne wartości. Należy więc ją oceniać, doskonalić, reformować. 


\section{PODSUMOWANIE}

Podjęte rozważania oparto na założeniu, że „teraźniejszość edukacji” jest zawsze powiązana z przeszłością i jej zmianami, które dokonały się i dokonują. Przyszłość zaś zależy od teraźniejszości i zmian, jakie dopiero nastąpią. Jednak aby były one owocne, powinny bazować na rzetelnej diagnozie stanu rzeczywistego, mocnych i słabych stron współczesnej edukacji z uwzględnieniem jej ważnych życiowych wartości i celów. Czy mamy świadomość wartości, które powinna uwzględniać szkoła? Są one bowiem niejako kryteriami oceny stanu edukacji i warunkami osiągania celów z tymi wartościami związanych. Jaka więc pedagogika jest potrzebna edukacji skierowanej na ważne życiowe wartości i kompetencje uczniów? Zapewne nie może być orzekająca ani milcząca, lecz musi stać się sprawcą rozwoju i pomyślności społeczeństwa (Kwieciński 1998) (jakim sprawcą? jakiego rozwoju? w jakim klimacie i warunkach? co to oznacza dla pedagogów?). Jakie składowe i cechy współczesnej edukacji warto więc ugruntowywać, wzmacniać i rozwijać? Co zaś wymaga zmian? Są to problemy badawcze, które uczelnie wyższe ze szkołami niższego szczebla powinny wspólnie analizować, rozstrzygać.

Problematyka ta towarzyszyła debatom XXIV Tatrzańskiego Sympozjum Naukowego w dniach 18-20 czerwca 2018 roku w Zakopanem. Autorka wygłosiła na nim referat na temat szkoły jako instytucji badanej i badającej, który został opublikowany w Edukacji jutra (Kocór 2018). Przyświecała mu przede wszystkim idea rozpoznania czynnego i biernego udziału szkoły oraz nauczycieli w badaniach opisujących i wyjaśniających poszczególne składniki edukacji. Za niezmiernie ważną należy uznać potrzebę badania szkoły od jej „wnętrza”. Trzeba szkołę mniej krytykować z zewnątrz, a bardziej troszczyć się o nią, rozumieć, doceniać i wspierać. Taka postawa zrozumienia jest typowa dla społeczeństwa obywatelskiego - świadomego, zaangażowanego, odpowiedzialnego za tworzenie lepszych warunków rozwoju różnych dziedzin życia, na czele z systemem edukacji, i troszczącego się o lepszą szkołę.

Jeśli zatem zmienimy wartości i dopasujemy do nich cele, to zmienią się planowanie, organizacja edukacji, kontrola oraz ocena jej wyników (według bardziej wartościowych, „życiowych” kryteriów) i mierników, jak też pedagogiczne podejście do zmian i reform szkolnych. Będzie to wymagało pracy nad wartościami oraz uczenia ich „przeżywania”, a w szczególności przywrócenia edukacji aksjologicznego wymiaru, jak również ukierunkowania na kształtowanie postaw i cech osobowości, które zmotywują uczniów do uczenia się oraz nabywania kompetencji życiowych. Gdy zaś dalej będą liczyć się głównie oceny z egzaminów i punkty

${ }^{1}$ W dziedzinie etnografii edukacyjnej ćwierć wieku temu ukazała się książka Ireneusza Kaweckiego pt. Etnografia i szkoła (1993) korelująca z badaniami Andrzeja Janowskiego (1989). 
w teście, świadectwa, zaświadczenia i inne biurokratyczne „zabiegi” (Kocór 2018b), to wciąż pod znakiem zapytania pozostaną społeczeństwo obywatelskie i możliwość wykorzystania jego kapitału na rzecz prorozwojowej zmiany.

\section{LITERATURA}

Dudzikowa M., 2001, Mit o szkole jako miejscu „wszechstronnego rozwoju” ucznia. Eseje etnopedagogiczne. Kraków, Oficyna Wydawnicza Impuls.

Janowski A., 1989, Uczeń w teatrze życia szkolnego. Warszawa, WSiP.

Kawecki I., 1993, Etnografia i szkoła. Łódź, Wydawnictwo Państwowej Wyższej Szkoły Sztuk Plastycznych.

Kocór M., 2006, Nauczyciele wobec zmian edukacyjnych w Polsce. Rzeszów, Wydawnictwo UR.

Kocór M., 2010, Szkoła i nauczyciel a syndrom wypalenia zawodowego. Rzeszów, Wydawnictwo Mitel.

Kocór M., 2011, Reforma oświaty w opinii nauczycieli. W: M.M. Kowalczyk, S. Cudak (red.), Innowacyjność. Studia - Badania - Egzemplifikacje. Łódź, Leader-Great Publishers.

Kocór M., 2012a, Kompetencje wychowawcy klasy w ocenie uczniów i nauczycieli. W: J. Kirenko, T. Zubrzycka-Maciąg, D. Wosik-Kowala (red.), Wychowawcza rola szkoły. Lublin, Wydawnictwo UMCS, 163-184.

Kocór M., 2012b, Autorytet wspótczesnego nauczyciela - oczekiwania a rzeczywistość. W: K. Denek, A. Kamińska, A. Łuszczyk i P. Oleśniewicz (red.), Edukacja jutra. Uczeń i nauczyciel jako główne podmioty edukacji jutra. Sosnowiec, Wydawnictwo Humanitas, 23-43.

Kocór M., 2012c, Nauczyciele wobec reformy oceniania (na przykładzie badań przeprowadzonych na terenie województwa podkarpackiego). „Edukacja i Dialog”, nr 234/235, 22-29.

Kocór M., 2012d, Jakich zmian potrzebuje polska szkoła? „Edukacja i Dialog”, nr 238/239, 28-36.

Kocór M., 2014a, Nauczyciel wobec reformy - reforma wobec nauczyciela. Ku polityce partnerstwa i dialogu edukacyjnego. W: K. Denek, A. Kamińska, P. Oleśniewicz (red.), Edukacja jutra. Systemowe aspekty organizacji szkolnictwa w Polsce. Sosnowiec, Wydawnictwo Humanitas, 49-62.

Kocór M., 2014b, Oczekiwania uczniów wobec szkoły w świetle badań prowadzonych na terenie województwa podkarpackiego. W: Sborník př́spěvků Mezinárodní Masarykovy konference pro doktorandy a mladé vědecké pracovníky. Hradec Králové, Magnanimitas, vyd. 5, 2522-2532. 
Kocór M., 2015a, Nauczyciel jako sprawca i ofiara kryzysu oświatowego w Polsce. W: K. Denek, A. Kamińska, P. Oleśniewicz (red.), Edukacja jutra. W poszukiwaniu formuły współczesnej edukacji. Sosnowiec, Wydawnictwo Humanitas, 55-70. Kocór M., 2015b, Problemy szkół i nauczycieli w małych środowiskach $w$ Polsce. W: Recenzowany sbornik př́spěvků vědecké konference s mezinárodní ucasti. Sapere Aude, Hradec Kralove, 321-330.

Kocór M., 2015c, Reforma szkolnictwa w doświadczeniach polskiego nauczyciela. Jakich potrzeba zmian? W: Š. Porubský, Z. Lynch (red.), Kurikulárna reforma a perspektívy základnej školy. Bańska Bystrzyca, UMB, 260-277.

Kocór M., 2016a, Szkoła jako źródło stresu $w$ trudnych sytuacjach $w$ realiach polskich. W: V. Stoffová, L. Zsakó, P. Szlávi (red.), New Methods and Technologies in Education and Practice: XXIXth Didmattech 2016. Budapeszt, Eötvös Loránd University [pozyskano z: http://didmattech.inf.elte.hu/proceedings/].

Kocór M., 2016b, Школа в умовах демократичних змін: від прав і можливостей до безпорадності польського вчителя, „Людинознавчі Студії: збірник наукових праць Дрогобицького державного педпгогічного університету імені Івана франка”. Серія „Педагогіка. Випуск” 3/35, 154-163.

Kocór M., 2016c, Kryzys nauczycielskiego autorytetu - przyczyny i konsekwencje. W: S. Neslušanová, M. Niklová, E. Jarosz (red.), Sociální pedagogika ve světle společenského, institucionálního a individuálního ohrožení. Brno, Institut Mezioborových Studií, 147-156.

Kocór M., 2016d, Myśl profesora Kazimierza Denka inspiracją naukowych dociekań i badań nad „dziś i jutro” edukacji szkolnej. W: A. Kamińska, E. Kraus, P. Oleśniewicz (red.), Edukacja jutra. Filozofia życia profesora Kazimierza Denka (1932-2016). Sosnowiec, Wydawnictwo Humanitas.

Kocór M., 2017, Dlaczego uczniowie nie lubia szkoły, a nauczyciele wypalają się w zawodzie? W: M. Prokešová (red.), Perspektivy výchovy a vzdělávání v podmínkách současného světa, Sborníky České pedagogické společnosti. Praha, Česká Pedagogická Společnost, 389-402.

Kocór M., 2018a, Szkoła jako miejsce wsparcia społecznego. „Edukacja - Technika Informatyka. Kwartalnik Naukowy", nr 1, 218-224.

Kocór M., 2018b, Szkoła jako instytucja badana i badająca szansa czy bariera edukacji jutra? W: A. Kamińska, P. Oleśniewicz (red.), Wiedza i edukacja w egzystencji współczesnego człowieka. Sosnowiec, Wydawnictwo Humanitas, 59-71.

Kwieciński Z., 1995, Socjopatologia edukacji. Olsztyn, MW Olecko.

Kwieciński Z., 1998, Zmienić kształcenie nauczycieli. W: A. Siemak-Tylikowska, H. Kwiatkowska, S.M. Kwiatkowski (red.), Edukacja nauczycielska w perspektywie wymagań zmieniającego się świata. Warszawa, Wydawnictwo Żak, 15-50.

Maszke A.W. (red.), 1995, Stałość i zmienność w naukach pedagogicznych. Olsztyn, WSP. 
Malach J., 2015, Rozvoj a hodnocení smyslu pro iniciativu a podnikavost žáků základních škol. Ostrava, Ostravská Univerzita.

Malach J., Kristová K., 2016b, Výzkum vztahu mezi vybranými proměnnýmipodnikavosti žáků základních škol a středních škol a jejich tvořivostí. W: J. Malach, I. Červenková, M. Chmura (red.), Pokroky v hodnocení klíčových kompetencí. Ostrava, Ostravská Univerzita, 46-59.

Sawisz A., 1989, Szkoła a system społeczny: wokół problematyki „nowej socjologii oświaty”. Warszawa, WSiP.

Szczepański J., 1989, Społeczne uwarunkowania rozwoju oświaty. Warszawa, WSiP.

Ustawa z dnia 14 grudnia 2016 r. Prawo oświatowe, 2017. Dz.U., poz. 59 i 949.

Woods P., 1986, Inside Schools. Ethnography in Education Research. London, Routledge and Kegan Paul.

\title{
PRESENT TIME AND CHANGE IN SCHOOL EDUCATION IN LIGHT OF OWN REFLEC- TION AND RESEARCH
}

\begin{abstract}
In the article the author accents the sense of education, its condition and specificity of changes that were made and are being made in Poland, which for almost thirty years have bet on democracy. Making use of empirical research conducted among teachers, as the main implementers of change, the author seeks their pedagogical dimension, wonders about the future of school education and its determinants. She emphasizes important life values. They are the same for years, like truth, goodness, beauty, human kindness, honesty and conscientiousness. Analyzing them leads to the conclusion that it is about time to return from a curved, uncertain and dangerous path to a straight, illuminated road, leading to education, that will become the national priority and the catalyst of development.
\end{abstract}

Keywords: school, education, present, change, development 